\title{
Chromosome polymorphisms affecting recombination and exophunotypic traits in Leptysma argentina (Orthoptera): a populational survey
}

\author{
Pablo C. Colombo*
}

\author{
Laboratorio de Genética, Departamento de Ciencias \\ Biológicas, Facultad de Ciencias Exactas y Naturales, \\ Universidad de Buenos Aires, Ciudad Universitaria, \\ Intendente Güiraldes y Costanera Norte, \\ 1428 Buenos Aires, Argentina.
}

Leptysma argentina is polymorphic for a centric fusion between pairs 3 and 6 of the basic complement, for interstitial $\left(S_{i}\right)$ and proximal $\left(S_{p}\right)$ supernumerary segments in the smallest member of the complement, and for a $B$-chromosome. Fusion $3 / 6$ is associated with several effects that would lead to a drastic reduction of recombination (Colombo 1987, 1988). Nine populations from the Argentine provinces of Buenos Aires, Entre Ríos and Santa Fe were analysed for total (T), proximal (P), interstitial (I) and distal (D) chiasma frequencies, and for the morphometrical characters tegmina length, total length, femur length, tibia length, thorax length and thorax height. There was a strong negative correlation of T, P and I frequencies, and a significant positive correlation of $D$, with fusion $3 / 6$ frequency. Fusion carriers were significantly bigger than basic homozygotes, leading to highly significant correlations of all morphometrical variables with fusion frequency.

The frequencies of the fusion, segment $S_{i}$ and the B-chromosome follow a geographical pattern. The uneven distribution of the fusion is explained by effects on several exo- and endophenotypic traits. The nonrandom distribution of the B-chromosome is attributed to differential tolerance under differing chromosomal, genetical and/or ecological environments. No significant effects were detected for segments but $S_{i}$ is geographically widespread, arguing against its neutrality, while the low frequency and even frequency distribution of $S_{p}$ suggests maintenance by mutation.

\section{INTRODUCTION}

Polymorphisms for centric fusions and inversions are frequently cited as chromosomal devices that allow a population to maintain certain regions of the genome free of recombination (Carson, 1958; Hewitt, 1979; John, 1981; Brussard, 1984). The relevance of these polymorphisms to the preservation of coadapted gene complexes is self-evident, and their intra- and interchromosome effects on recombination (measured either through genetic or cytogenetic approaches) are well known (White and Morley, 1955; Lucchesi, 1976; John, 1981; Brussard, 1984). Nevertheless, there are no clear examples of chromosome rearrangements affecting exophenotypic traits (John, 1983).

Leptysma argentina Bruner (Leptysminae: Acrididae) is a South-American grasshopper that lives in relation with semiaquatic flora (Amedeg-

\footnotetext{
* Fellow of the Consejo Nacional de Investigaciones Científicas y Técnicas (CONICET).
}

nato, 1974; Roberts, 1978). In previous studies (Amoedo, 1979; Bidau and Hasson, 1984) this species was shown to be polymorphic for a centric fusion, a large supernumerary segment and a Bchromosome. The polymorphic centric fusion has been demonstrated to be associated with several intra- and interchromosomal effects that would lead to a strong reduction in recombination levels (Colombo, 1987). In the present paper, nine populations of this species were analysed in order to understand the importance of these polymorphisms to such relevant parameters as recombination, estimated through chiasma frequency and position, and exophenotypic traits, and to infer as far as possible and probable causes of their maintenance in natural populations of L. argentina.

\section{MATERIAL AND METHODS}

Three hundred and eight male individuals of $L$. argentina Bruner were collected in the meiotic 
season for this species (September-December) between 1983 and 1986 in nine localities of Santa $\mathrm{Fe}$, Entre Ríos and Buenos Aires. A list of the localities and their abbreviations is given in table 1 , and in the map of fig. 1 their geographic situation is shown. Individuals were dissected in the field and testes were fixed in $3: 1$ methanol: acetic acid and subsequently stored at $4^{\circ} \mathrm{C}$. Cytological preparations were made by squashing follicles in lactoproprionic orcein. For each individual the karyotype was determined and ten metaphase I plates were analysed for total $(\mathrm{T})$, proximal $(\mathrm{P})$, interstitial (I) and distal (D) chiasma frequency. Morphological measures (tegmina length, total length, femur length, tibia length, thorax length and thorax height) were determined with the aid of a graduated binocular microscope. In order to avoid the variable abdomen associated with feeding, total length was considered from the frontal
Table 1 Provenance, size and date of collection of the nine populations of Leptysma argentina

Localities

Province of Buenos Aires

Zárate (Z)

Isla Talavera (IT)

Puerto Talavera (PT)

Pilar (P)

Río Luján (RL)
16 September 1984

10 December 1985

75 October to December 1986

13 September $1985^{*}$

98 November-December 1983

October-December 1984
Province of Entre Ríos (Parque Nacional "El Palmar")

Arroyo de los Loros (LL) 20 December 1985

Yarará Guazú (YG) 25 December 1986

Arroyo El Palmar (EP) 34 December 1985

Province of Santa $\mathrm{Fe}$

Santa Fe (SF) 13 December 1986

Total

308

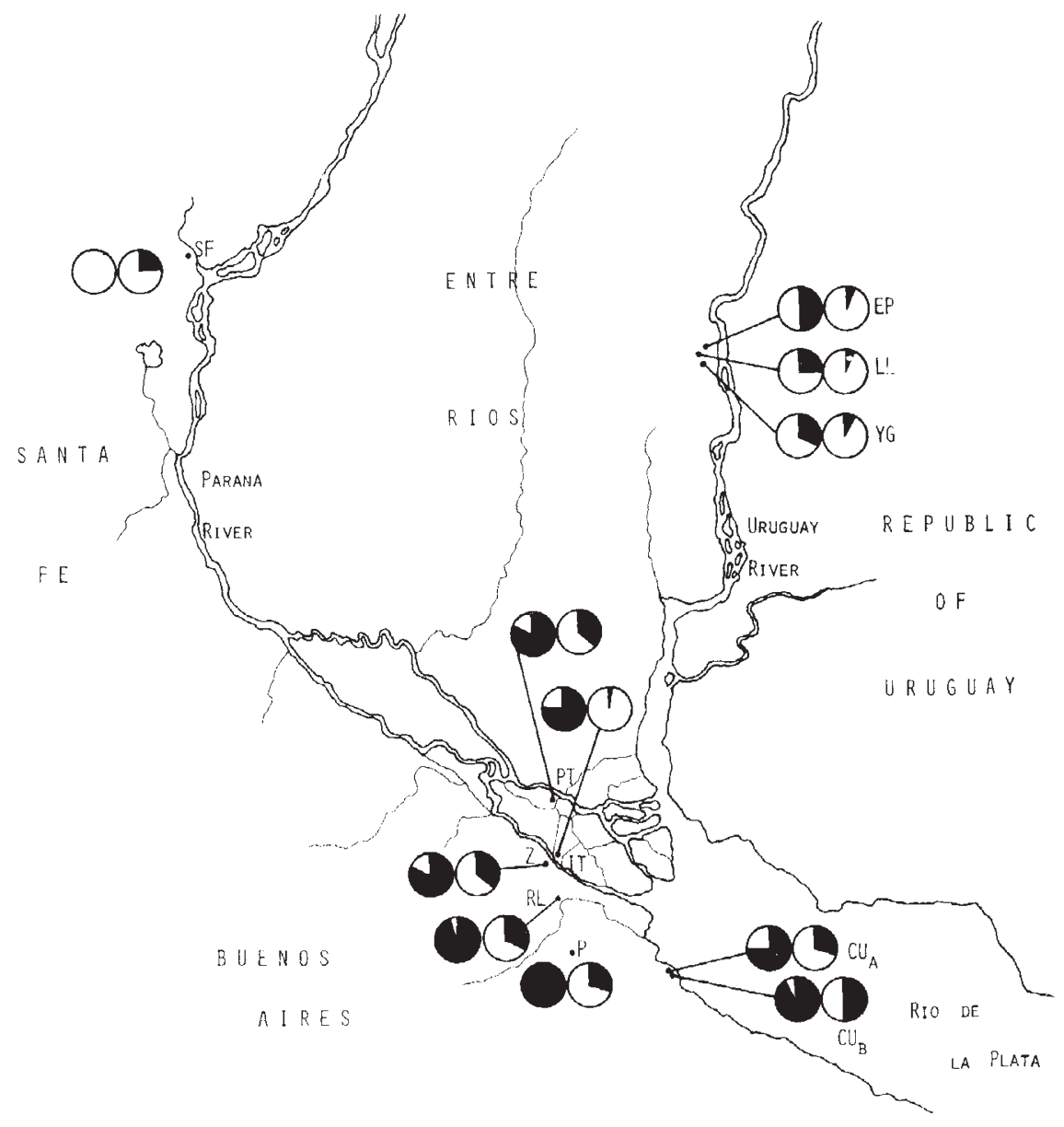

Figure 1 Map showing the distribution of fusion $3 / 6$ and segment $S_{i}$ polymorphisms as pie diagrams, the filled area representing relative frequency of each. Left circle: fusion 3/6; right circle: segment $S_{1}$. Populations $\mathrm{CU}_{\mathrm{A}}$ and $\mathrm{CU}_{\mathrm{B}}$ from the study of Bidau and Hasson (1984). 


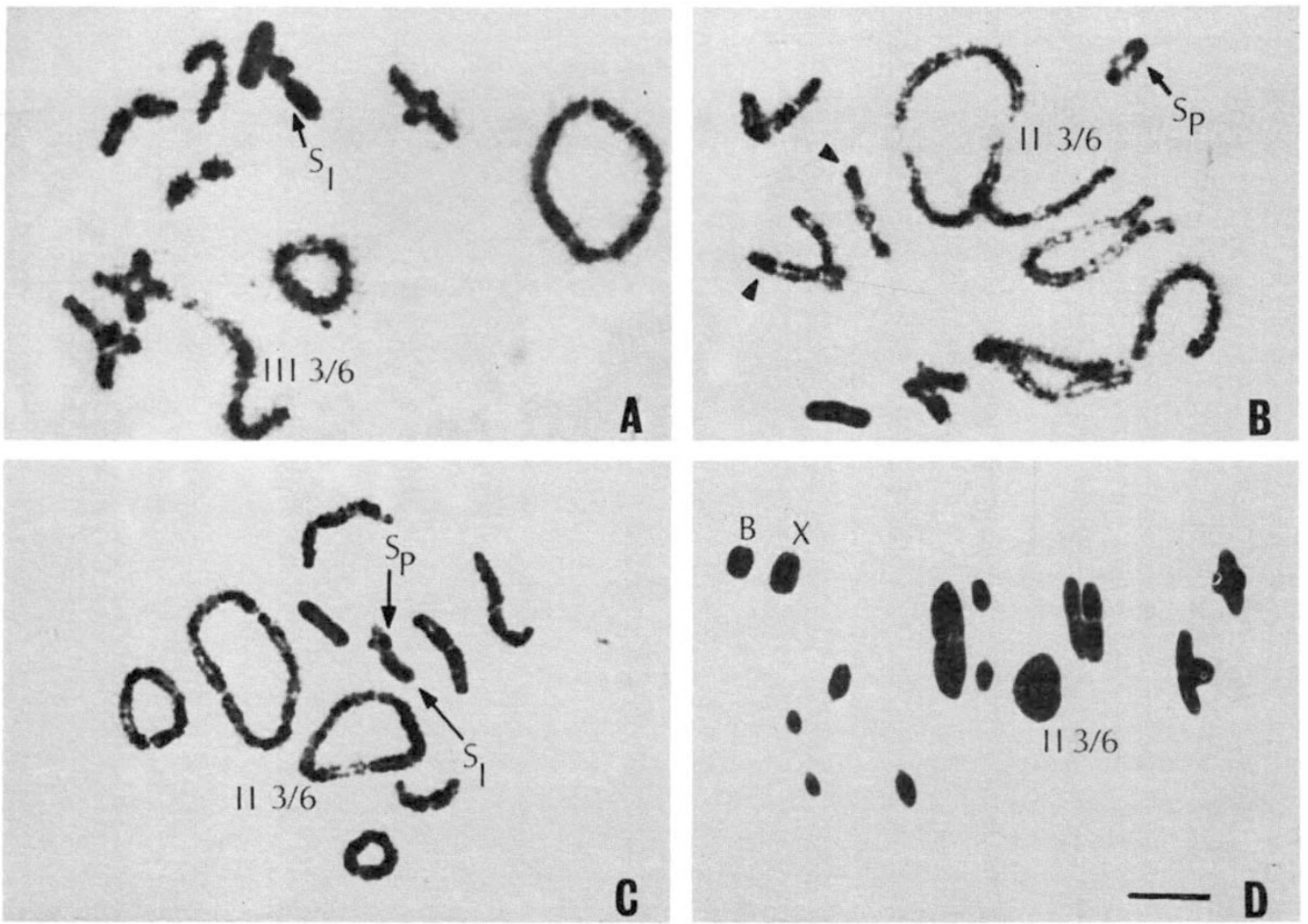

Figure 2 (a) Diplotene; double heterozygote for both the centric fusion $3 / 6$ and the interstitial segment $S_{j}$ (arrow). (b) Supernumerary segments on pairs 4 and 9 (arrowheads) that appear at low frequencies in the populations are also shown. (c) Diplotene: fusion homozygote carrying both supernumerary segments on pair 10 (arrows). (d) Metaphase I: fusion homozygote carrying a B-chromosome (B). III 3/6: trivalent 3-3/6-6. II 3/6: bivalent 3/6-3/6. $\mathrm{Bar}=10 \mu \mathrm{m}$.

extreme of the fastigium to the articulation between femur and tibia (Ronderos, personal communication).

\section{RESULTS}

\section{Basic karyotype and chromosome polymorphisms}

The karyotype of $L$. argentina was described by Bidau and Hasson (1984). In its basic form it consists of 21 chromosomes in the male $(20 \mathrm{~A}+$ $\mathrm{XO}$ ), with the biggest pair being metacentric and the remaining ones telocentric. In nearly all populations so far studied two chromosome polymorphisms were present: one of them is a centric fusion between chromosomes three and six of the basic complement (fig. 2) and the other polymorphism is a heterochromatic supernumerary segment $\left(\mathrm{S}_{\mathrm{i}}\right)$ in the interstitial region of pair 10 (fig. 2). Some populations (especially those where a large sample was obtained) were also polymorphic for a supernumerary segment $\left(S_{p}\right)$ in the centromeric region of pair 10 (fig. 2(b), (c)). This segment displays a continuous variation in size, and ranges from a small heterochromatic knob (fig. 2(b), (c)) in most of the cases to a segment that duplicates the size of chromosome 10. Finally, a partially euchromatic $\mathrm{B}$-chromosome whose size is comparable to that of the $\mathrm{X}$ chromosome was detected in all wellrepresented populations (fig. 2(d)) (table 2).

\section{Frequencies of the polymorphism}

The frequencies of all four polymorphisms analysed are summarised in table 2 . Both the centric fusion and the interstitial supernumerary segment display a considerable frequency variation between populations, and are schematically represented in fig. 1; in this map the two populations studied by Bidau and Hasson (1984) are included. The frequencies of both the centric fusion and the supernumerary segment increase southwards. The two variables are represented in a biaxial system in fig. 3. The grouping of populations in this graphic, given by chromosome frequencies, is 
Table 2 Observed (O) and expected (E) frequencies, according to the Hardy-Weinberg formula, of the centric fusion and the supernumerary segments, and the frequencies of the B-chromosome in all nine populations of Leptysma argentina. In the case of the RL population, data from both collections (1983 and 1984) are given. Whenever the size of the sample allowed a statistical analysis, karyomorph frequencies did not depart significantly from Hardy-Weinberg expectations. BH: basic homozygote; $\mathrm{H}$ : heterozygote; $\mathrm{SH}$ : structural homozygote. $q=$ frequency of the rearrangement. For abbreviations of localities see table 1

\begin{tabular}{|c|c|c|c|c|c|c|c|c|}
\hline & & \multicolumn{2}{|c|}{ Fusion } & \multicolumn{2}{|l|}{$S_{i}$} & \multicolumn{2}{|l|}{$S_{p}$} & \multirow[b]{2}{*}{ B-chromosome } \\
\hline & & $\mathrm{O}$ & $\mathrm{E}$ & $\mathrm{O}$ & $\mathrm{E}$ & $\mathrm{O}$ & $\mathrm{E}$ & \\
\hline $\mathrm{SF}$ & $\begin{array}{l}\mathrm{BH} \\
\mathrm{H} \\
\mathrm{SH} \\
q\end{array}$ & $\frac{13}{-}$ & $\begin{array}{r}13 \\
0 \\
0\end{array}$ & $\begin{array}{r}7 \\
6 \\
- \\
0\end{array}$ & $\begin{array}{l}7.69 \\
4.62 \\
0.69\end{array}$ & $\begin{array}{r}12 \\
-1 \\
0 \cdot 0\end{array}$ & $\begin{array}{r}12.02 \\
0.96 \\
0.02\end{array}$ & $f(\mathrm{~B})=0 \cdot 23$ \\
\hline LL & $\begin{array}{l}\mathrm{BH} \\
\mathrm{H} \\
\mathrm{SH} \\
q\end{array}$ & $\begin{array}{c}12 \\
6 \\
2 \\
0 \cdot 2\end{array}$ & $\begin{array}{c}11 \cdot 25 \\
7 \cdot 5 \\
1 \cdot 25\end{array}$ & $\begin{array}{r}17 \\
2 \\
1 \\
0 .\end{array}$ & $\begin{array}{r}16 \cdot 2 \\
3 \cdot 6 \\
0 \cdot 2\end{array}$ & $\begin{array}{r}16 \\
-4 \\
0 \cdot 1\end{array}$ & $\begin{array}{r}16 \cdot 2 \\
3 \cdot 6 \\
0 \cdot 2\end{array}$ & $f(\mathrm{~B})=0.15$ \\
\hline YG & $\begin{array}{l}\mathrm{BH} \\
\mathrm{H} \\
\mathrm{SH} \\
q\end{array}$ & $\begin{array}{c}9 \\
13 \\
3 \\
0 \cdot 3\end{array}$ & $\begin{array}{r}9.61 \\
11.78 \\
3.61\end{array}$ & $\begin{array}{r}19 \\
6 \\
- \\
0\end{array}$ & $\begin{array}{r}19 \cdot 36 \\
5 \cdot 28 \\
0 \cdot 36\end{array}$ & $\begin{array}{r}23 \\
- \\
-0.0\end{array}$ & $\begin{array}{r}23.04 \\
1.92 \\
0.04\end{array}$ & $f(\mathrm{~B})=0 \cdot 12$ \\
\hline EP & $\begin{array}{l}\mathrm{BH} \\
\mathrm{H} \\
\mathrm{SH} \\
q\end{array}$ & $\begin{array}{c}8 \\
18 \\
8 \\
0 \cdot 5\end{array}$ & $\begin{array}{c}8 \cdot 5 \\
17 \\
8 \cdot 5\end{array}$ & $\begin{array}{r}28 \\
6 \\
- \\
0\end{array}$ & $\begin{array}{r}28 \cdot 26 \\
5 \cdot 47 \\
0 \cdot 26\end{array}$ & $\begin{array}{r}32 \\
2 \\
- \\
0.0\end{array}$ & $\begin{array}{r}32 \cdot 03 \\
1.94 \\
0 \cdot 03\end{array}$ & $f(\mathrm{~B})=0.03$ \\
\hline Z & $\begin{array}{l}\mathrm{BH} \\
\mathrm{H} \\
\mathrm{SH} \\
q\end{array}$ & $\begin{array}{l}7 \\
9 \\
0 \cdot 78\end{array}$ & $\begin{array}{l}0.77 \\
5.47 \\
9.77\end{array}$ & $\begin{array}{l}6 \\
7 \\
3 \\
0 .\end{array}$ & $\begin{array}{l}6 \cdot 64 \\
7 \cdot 71 \\
2 \cdot 64\end{array}$ & $\frac{16}{-}$ & $\begin{array}{r}16 \\
0 \\
0\end{array}$ & $f(B)=0 \cdot 0$ \\
\hline PT & $\begin{array}{l}\mathrm{BH} \\
\mathrm{H} \\
\mathrm{SH} \\
q\end{array}$ & $\begin{array}{r}2 \\
22 \\
43 \\
0 \cdot 8\end{array}$ & $\begin{array}{r}2 \cdot 55 \\
21 \cdot 03 \\
43 \cdot 52\end{array}$ & $\begin{array}{r}21 \\
36 \\
10 \\
0 .\end{array}$ & $\begin{array}{l}22 \cdot 7 \\
32 \cdot 59 \\
11 \cdot 7\end{array}$ & $\begin{array}{l}59 \\
7 \\
1 \\
0 \cdot 0\end{array}$ & $\begin{array}{c}58 \cdot 3 \\
8 \cdot 39 \\
0 \cdot 3\end{array}$ & $f(\mathrm{~B})=0.015$ \\
\hline IT & $\begin{array}{l}\mathrm{BH} \\
\mathrm{H} \\
\mathrm{SH} \\
q\end{array}$ & $\begin{array}{l}1 \\
2 \\
7 \\
0 \cdot 8\end{array}$ & $\begin{array}{l}0 \cdot 4 \\
3 \cdot 2 \\
6 \cdot 4\end{array}$ & $\begin{array}{r}9 \\
1 \\
- \\
0\end{array}$ & $\begin{array}{l}9.03 \\
0.99 \\
0.03\end{array}$ & $\frac{10}{-}$ & $\begin{array}{r}10 \\
0 \\
0\end{array}$ & $f(\mathrm{~B})=0 \cdot 0$ \\
\hline $\begin{array}{l}\text { RL } \\
(1983)\end{array}$ & $\begin{array}{l}\mathrm{BH} \\
\mathrm{H} \\
\mathrm{SH} \\
q\end{array}$ & $\begin{array}{r}3 \\
6 \\
41 \\
0.8\end{array}$ & $\begin{array}{r}0.7 \\
10 \cdot 6 \\
38.7\end{array}$ & $\begin{array}{r}26 \\
18 \\
6 \\
0 .\end{array}$ & $\begin{array}{l}24 \cdot 5 \\
21 \\
4 \cdot 5\end{array}$ & $\begin{array}{c}25 \\
16 \\
9 \\
0 \cdot 3\end{array}$ & $\begin{array}{r}21 \cdot 8 \\
22 \cdot 4 \\
5 \cdot 8\end{array}$ & $f(\mathrm{~B})=0.05$ \\
\hline $\begin{array}{l}\text { RL } \\
(1984)\end{array}$ & $\begin{array}{l}\mathrm{BH} \\
\mathrm{H} \\
\mathrm{SH} \\
q\end{array}$ & $\begin{array}{l}-\overline{12} \\
36 \\
0.8\end{array}$ & $\begin{array}{r}0.8 \\
10 \cdot 5 \\
36 \cdot 7\end{array}$ & $\begin{array}{r}27 \\
18 \\
3 \\
0 .\end{array}$ & $\begin{array}{r}27 \\
18 \\
3\end{array}$ & $\begin{array}{l}40 \\
7 \\
1 \\
0 \cdot 0\end{array}$ & $\begin{array}{r}39.4 \\
8.2 \\
0.4\end{array}$ & $f(\mathrm{~B})=0.06$ \\
\hline$P$ & $\begin{array}{l}\mathrm{BH} \\
\mathrm{H} \\
\mathrm{SH} \\
q\end{array}$ & $\frac{-}{13}+0$ & $\begin{array}{r}0 \\
0 \\
13\end{array}$ & $\begin{array}{l}6 \\
5 \\
2 \\
0 .\end{array}$ & $\begin{array}{l}5 \cdot 56 \\
5 \cdot 88 \\
1 \cdot 56\end{array}$ & $\frac{13}{-}$ & $\begin{array}{r}13 \\
0 \\
0\end{array}$ & $f(\mathrm{~B})=0 \cdot 0$ \\
\hline
\end{tabular}

consistent with the geographic provenance; populations that are geographically near to each other display quite similar chromosome frequencies. The only exception to this pattern is the IT population, that shows an unexpectedly low frequency of $S_{i}$ in comparison to the neighbouring populations (fig. 2 ). This population is very recent, and the small pond where the sample was collected was pro- duced in 1977 by human activity. The pond is periodically subject to desiccation and disturbance by man. Hence, it is probable that the low frequency of $S_{i}$ in IT reflect a recent founder effect or the operation of random drift.

A double correlation analysis between longitude and latitude and each of the frequencies of all four polymorphisms was performed in order to 
Table 3 Mean total (T), proximal (P), interstitial (I) and distal (D) chiasma frequency per population and frequency of the fusion chromosome $3 / 6(q)$ of Leptysma argentina. $r=$ correlation coefficient between chiasma values and fusion frequency. $P$ : level of significance of $r$

\begin{tabular}{|c|c|c|c|c|c|c|c|}
\hline Population & $q$ & $\mathrm{~T}$ & $P$ & I & $\mathrm{D}$ & $\begin{array}{l}\text { Number of } \\
\text { indiv. }\end{array}$ & $\begin{array}{l}\text { Number of } \\
\text { cells }\end{array}$ \\
\hline SF & $0 \cdot 00$ & $15 \cdot 35$ & $5 \cdot 08$ & $3 \cdot 25$ & $7 \cdot 02$ & 13 & 130 \\
\hline LL & 0.25 & 14.71 & $4 \cdot 12$ & $3 \cdot 18$ & $7 \cdot 41$ & 17 & 170 \\
\hline YG & $0 \cdot 38$ & 14.68 & 3.98 & $2 \cdot 63$ & $8 \cdot 16$ & 25 & 250 \\
\hline EP & 0.50 & 13.89 & 3.66 & 1.78 & 8.45 & 29 & 290 \\
\hline $\mathrm{Z}$ & 0.78 & 13.81 & $2 \cdot 78$ & $2 \cdot 09$ & 7.94 & 15 & 150 \\
\hline PT & 0.80 & $13 \cdot 50$ & $3 \cdot 21$ & 1.65 & 8.64 & 25 & 250 \\
\hline IT & 0.80 & $12 \cdot 76$ & $2 \cdot 32$ & 1.83 & $8 \cdot 61$ & 8 & 80 \\
\hline RL & 0.89 & $12 \cdot 87$ & $2 \cdot 71$ & 1.60 & $8 \cdot 56$ & 41 & 410 \\
\hline $\mathrm{P}$ & 1.00 & 12.75 & $2 \cdot 27$ & $2 \cdot 08$ & $8 \cdot 39$ & 11 & 110 \\
\hline$r$ & - & -0.95 & -0.95 & -0.85 & $0 \cdot 83$ & - & - \\
\hline$P$ & - & $<0.001$ & $<0.001$ & $<0.001$ & 0.0016 & - & - \\
\hline Total & - & - & - & - & - & 154 & 1540 \\
\hline
\end{tabular}

evaluate the degree of association between geographic provenance of the population and chromosome frequencies. The analysis was carried out both including and excluding the IT population, because of its peculiarities. Correlation was very high for the centric fusion $(r=0.95$ and $r=0.93$ with and without IT, respectively); a weaker but also significant association was found for the Bchromosome ( $r=0.63$ and $r=0.68)$ and no association was found for the $S_{\mathrm{p}}$ segment $(r=0.37$ and $r=0.41)$. The $\mathrm{S}_{\mathrm{i}}$ segment showed a significant but weak association when IT was included $(r=0.61)$ and a much higher one when it was excluded $(r=0.93)$.

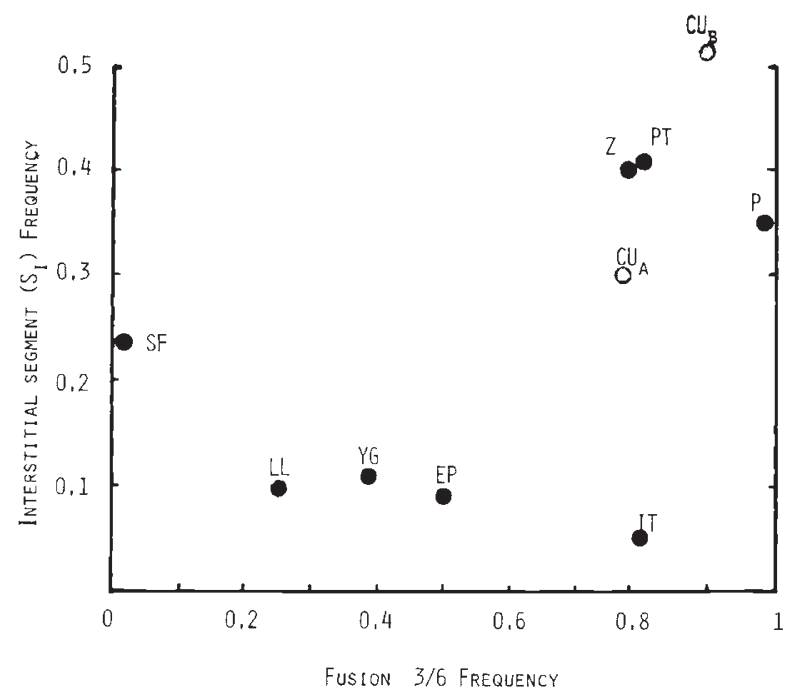

Figure 3 Frequency of the segment $S_{i}$ plotted against fusion $3 / 6$ frequency. White circles $\left(\mathrm{CU}_{\mathrm{A}}\right.$ and $\left.\mathrm{CU}_{\mathrm{B}}\right)$ belong to the populations studied by Bidau and Hasson (1984).
In the population of Río Luján karyotypic frequencies were monitored in two consecutive years (1983 and 1984). The centric fusion, the interstitial segment and the B-chromosome displayed quite similar frequencies in 1983 and 1984; by contrast, the frequency of the proximal segment dropped from 0.33 in 1983 to 0.09 in 1984 (table 2). A third analysis in 1985 was impossible because the region sampled was converted into a camping site.

\section{Chiasma frequency and position}

Fusion $3 / 6$ has pronounced intra- and interchromosome effects on chiasma conditions; in fact, the fusion carriers have a reduced chiasma frequency as a result of partial suppression of proximal and interstitial chiasmata; this effect is more marked in fusion homozygotes than in heterozygotes (Colombo, 1987, 1988a). As a consequence of this, it is expected that populations with different frequencies of the fused chromosome will also differ in their mean chiasma frequency and position per population. On the contrary, neither the supernumerary segments nor the B-chromosome seem to affect chiasma conditions (unpublished data of the author). A total of 154 individuals were analysed for total ( $\mathrm{T})$, proximal (P), interstitial (I) and distal (D) chiasma frequency; in each one ten metaphase I cells were scored and the mean value per cell per individual was obtained; in table 3 the averaged values per population are represented, together with chromosome $3 / 6$ frequency (q). The correlation of $T, P$ and $I$ with fusion frequency was negative and highly significant; on the other hand, correlation 
of $\mathrm{D}$ with fusion frequency was positive and significant (table 3 ). It is worth noting that, whereas $\mathrm{T}$ and $\mathrm{P}$ lines are nearly parallel with each other, $I$ and $D$ ones are nearly mirror images of one another (figs. 4(a) and 4(b)). A correlation analysis was consequently carried out between: (a) mean $T$ and $P$ chiasma frequencies, and (b) mean I and $\mathrm{D}$ chiasma frequencies. The degree of association was very high in both cases, being positive for (a) $(r=0.966, P<0.001)$ and negative for (b) $r=$ $-0.988, P<0.001)$.

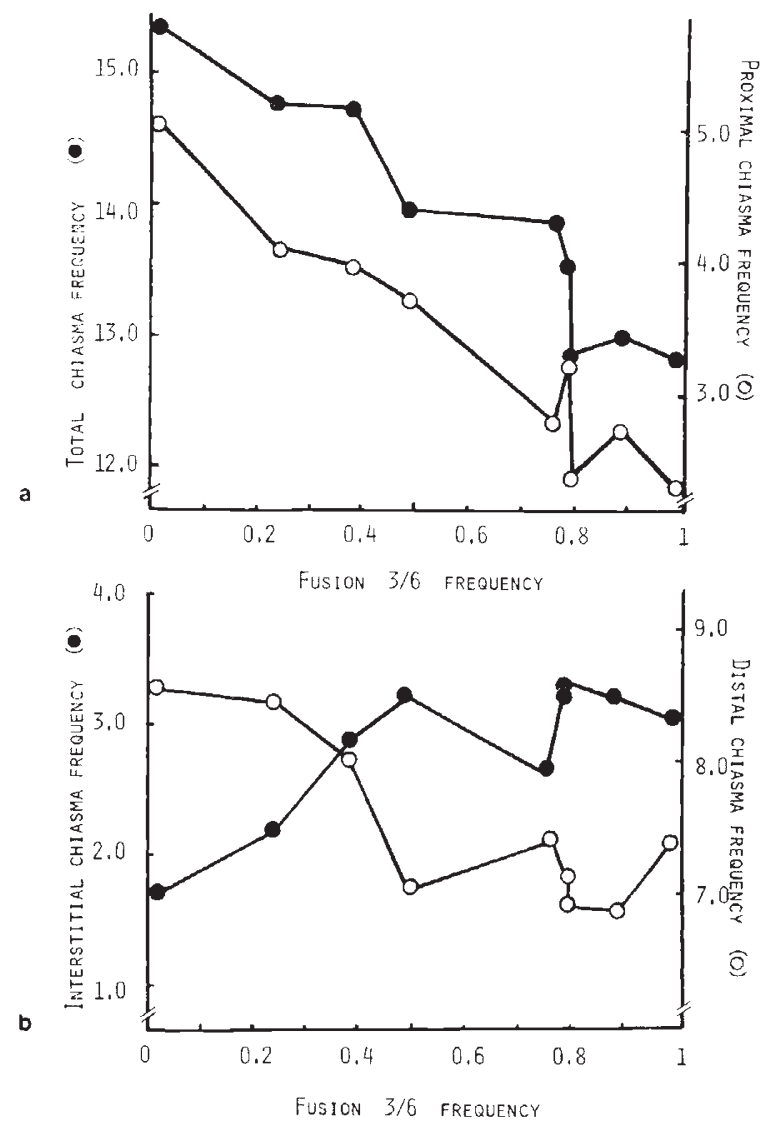

Figure 4 Total (O), proximal (O) (upper graphic), interstitial (O) and distal (O) (lower graphic) mean chiasma frequencies per population plotted against fusion $3 / 6$ frequency in all nine populations of $L$. argentina.

\section{Effects of polymorphisms on exomorphological traits}

With the aim of determining whether the centric fusion, the interstitial segment or both exert any influence on body size, a morphometrical study was performed. First, intrapopulational (between karyomorphs) studies were carried out in order to determine with certainty whether the effects are indeed attributable to the rearrangement. Also, a correlation analysis was carried out in order to determine the degree of association between body measures and fusion frequencies in different populations.

\subsection{The populations of "El Palmar" and Puerto Talavera}

All three populations from National Park "El Palmar" (Arroyo de los Loros, Yarará Guazú and Arroyo El Palmar) were pooled in order to provide enough individuals to perform the statistical analyses, given that those populations are only a few kilometers apart. The results are summarised in table 4(a). It was found that fusion carriers are bigger, on the whole, than basic homozygotes, and this effect is more marked in fusion homozygotes than in heterozygotes. Differences between karyomorphs were significant in all cases, except for femur length. An analogous statistical analysis was developed with individuals from Puerto Talavera; as no basic homozygotes were measured here, differences between karyomorphs are expected to be smaller (and they are). In this population it was also evident that fusion homozygotes are bigger than heterozygotes, although only the ANOVAs comparing total and thorax length gave significant differences (table 4(b)). In this population it was also possible to test for differences between carriers and non-carriers for the interstitial segment; however, in all cases differences were not significant.

\subsection{Correlation of morphometric variables with fusion $3 / 6$ frequency}

Having demonstrated the significant effect of fusion $3 / 6$ on body size (fig. 5), the correlations between the frequency of that rearrangement and mean morphological variables in all nine populations were examined. The results of this analysis are summarised in table 5 . Correlation with fusion $3 / 6$ frequency was highly significant for all characters measured.

\section{DISCUSSION}

Polymorphisms for centric fusions have a twofold effect on recombination. First, a new linkage group is built up that severely reduces the possible number of chromosome combinations (White, 1973). 
Table 4 Effects of the centric fusion $3 / 6$ on morphometrical characters in (a) the pooled populations of Parque Nacional "El Palmar" (LL + YG + EP) and (b) Puerto Talavera (PT) population. Measures are expressed in milimeters. All karyomorphs were compared by means of one-way analyses of variance. The number of individuals measured in each case is given between parentheses below the mean value for each character. $F=$ variance ratio. $P=$ level of significance

\begin{tabular}{|c|c|c|c|c|c|c|}
\hline \multirow[b]{2}{*}{ Karyomorphs } & \multicolumn{6}{|c|}{ Characters analysed } \\
\hline & $\begin{array}{l}\text { Total } \\
\text { length }\end{array}$ & $\begin{array}{l}\text { Tegmina } \\
\text { length }\end{array}$ & $\begin{array}{l}\text { Femur } \\
\text { length }\end{array}$ & $\begin{array}{l}\text { Tibia } \\
\text { length }\end{array}$ & $\begin{array}{l}\text { Thorax } \\
\text { length }\end{array}$ & $\begin{array}{l}\text { Thorax } \\
\text { height }\end{array}$ \\
\hline \multicolumn{7}{|l|}{ (a) "El Palmar" } \\
\hline Basic & $24 \cdot 56$ & $24 \cdot 53$ & $11 \cdot 81$ & $10 \cdot 19$ & $3 \cdot 83$ & $2 \cdot 83$ \\
\hline homozygotes & $(25)$ & (15) & $(15)$ & (24) & $(25)$ & $(22)$ \\
\hline \multirow[t]{2}{*}{ Heterozygotes } & $24 \cdot 94$ & $24 \cdot 85$ & $11 \cdot 86$ & $10 \cdot 40$ & 3.90 & 2.79 \\
\hline & (35) & (23) & $(35)$ & (34) & $(35)$ & $(32)$ \\
\hline Fusion & $25 \cdot 35$ & $25 \cdot 65$ & 12.07 & $10 \cdot 59$ & $4 \cdot 00$ & $2 \cdot 96$ \\
\hline homozygotes & (13) & (10) & (13) & (13) & (13) & (11) \\
\hline$F$ & $4 \cdot 32$ & $4 \cdot 02$ & $1 \cdot 22$ & $4 \cdot 53$ & $6 \cdot 51$ & $3 \cdot 24$ \\
\hline$P$ & $0.017^{*}$ & 0.025 & $0.30 \mathrm{~ns}$ & $0.01^{*}$ & $0.003^{* *}$ & $0.046^{*}$ \\
\hline \multicolumn{7}{|c|}{ (b) Puerto Talavera } \\
\hline \multirow[t]{2}{*}{ Heterozygotes } & 24.95 & $25 \cdot 11$ & $12 \cdot 21$ & $10 \cdot 55$ & $4 \cdot 00$ & $2 \cdot 96$ \\
\hline & (19) & (19) & (19) & (19) & (19) & (19) \\
\hline Fusion & $25 \cdot 46$ & $25 \cdot 66$ & $12 \cdot 41$ & $10 \cdot 76$ & $4 \cdot 16$ & 2.97 \\
\hline homozygotes & $(36)$ & $(32)$ & $(36)$ & $(36)$ & $(36)$ & (36) \\
\hline$F$ & $4 \cdot 93$ & $2 \cdot 34$ & $2 \cdot 57$ & $2 \cdot 89$ & $5 \cdot 46$ & 0.03 \\
\hline$P$ & $0.03^{*}$ & $0.13 \mathrm{~ns}$ & $0.11 \mathrm{~ns}$ & $0.09 \mathrm{~ns}$ & $0.02^{*}$ & $0.86 \mathrm{~ns}$ \\
\hline
\end{tabular}

Second, a chiasma readjustment is necessary in order to preclude the formation of proximal chiasmata in the trivalent, which would result in its malorientation (Sybenga, 1975; Hewitt, 1979). Hence, a centric fusion polymorphism has, to a large extent, the same genetic consequencees as inversion polymorphisms in Drosophila, that is, a progressive genetic differentiation between both the fused and non-fused chromosomes. Unfortunately, there are few genuine cases of centric fusion polymorphisms so far described in which chiasma studies have been performed (Hewitt and Schroeter, 1968; Bidau, 1984).

Although much attention has been paid to the effects of chromosome rearrangements on recombination (White and Morley, 1955; Lucchesi, 1976; Hewitt and John, 1972; John and Freeman, 1975; John, 1981) there are few examples of position effects caused by chromosome rearrangements that affect exomorphological traits (John, 1983). This lack of clear evidence has led to some authors, like Lande (1979), to conclude that chromosome rearrangements seldom or never have significant effects on the exophenotype. In this context the case of $L$. argentina is interesting since both chiasma conditions and morphometrical charac- ters are affected in this species by a polymorphic centric fusion.

As a first point of discussion it is evident that, whereas the segment $S_{p}$ is randomly distributed

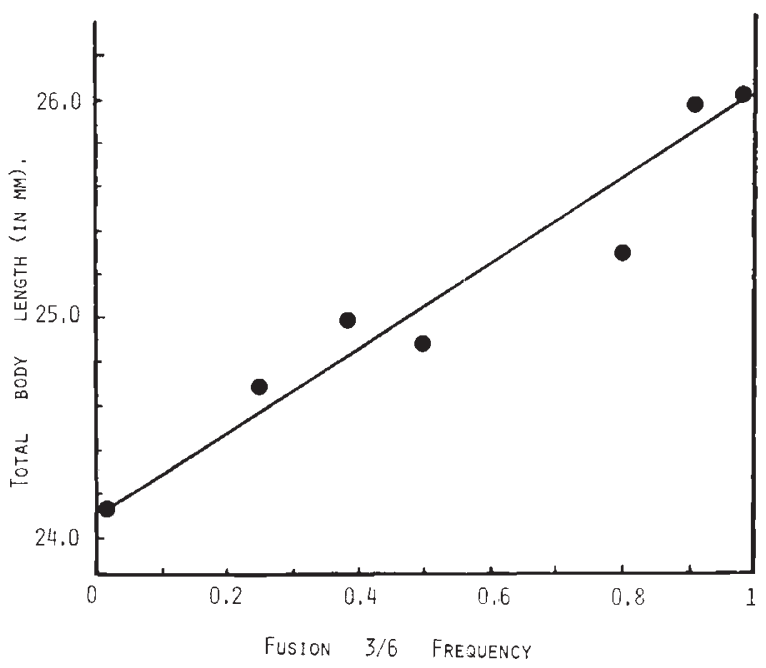

Figure 5 Mean total body length per population plotted against fusion $3 / 6$ frequency in all nine populations of $L$. argentina. 
Table 5 Mean morphometrical measures per population, and their correlation $(r)$ with fusion $3 / 6$ frequencies. The number of individuals analysed in each case is given between parentheses below the mean value. $P=$ level of significance of $r$

\begin{tabular}{|c|c|c|c|c|c|c|c|}
\hline \multirow[b]{2}{*}{ Population } & \multicolumn{7}{|c|}{ Characters analysed } \\
\hline & $\begin{array}{l}\text { Fusion } \\
\text { freq. }\end{array}$ & $\begin{array}{l}\text { Total } \\
\text { length }\end{array}$ & $\begin{array}{l}\text { Tegmina } \\
\text { length }\end{array}$ & $\begin{array}{l}\text { Femur } \\
\text { length }\end{array}$ & $\begin{array}{l}\text { Tibia } \\
\text { length }\end{array}$ & $\begin{array}{l}\text { Thorax } \\
\text { length }\end{array}$ & $\begin{array}{l}\text { Thorax } \\
\text { height }\end{array}$ \\
\hline SF & $0 \cdot 0$ & $\begin{array}{l}24 \cdot 15 \\
(13)\end{array}$ & $\begin{array}{l}24 \cdot 46 \\
(13)\end{array}$ & $\begin{array}{l}11 \cdot 42 \\
(13)\end{array}$ & $\begin{array}{l}10 \cdot 08 \\
(13)\end{array}$ & $\begin{array}{l}3 \cdot 74 \\
(13)\end{array}$ & $\begin{array}{l}2 \cdot 79 \\
(13)\end{array}$ \\
\hline LL & $0 \cdot 25$ & $\begin{array}{l}24 \cdot 68 \\
(17)\end{array}$ & $\begin{array}{l}25 \cdot 15 \\
(13)\end{array}$ & $\begin{array}{l}11.85 \\
(17)\end{array}$ & $\begin{array}{l}10 \cdot 30 \\
(17)\end{array}$ & $\begin{array}{l}3 \cdot 88 \\
(17)\end{array}$ & $\begin{array}{l}2 \cdot 86 \\
(17)\end{array}$ \\
\hline YG & $0 \cdot 38$ & $\begin{array}{l}24.98 \\
(24)\end{array}$ & $\begin{array}{l}24 \cdot 56 \\
(18)\end{array}$ & $\begin{array}{l}11.98 \\
(24)\end{array}$ & $\begin{array}{l}10 \cdot 51 \\
(23)\end{array}$ & $\begin{array}{l}3 \cdot 88 \\
(24)\end{array}$ & $\begin{array}{l}2 \cdot 79 \\
(24)\end{array}$ \\
\hline EP & $0 \cdot 50$ & $\begin{array}{l}24 \cdot 89 \\
(32)\end{array}$ & $\begin{array}{l}24 \cdot 98 \\
(24)\end{array}$ & $\begin{array}{l}11 \cdot 83 \\
(32)\end{array}$ & $\begin{array}{l}10 \cdot 29 \\
(32)\end{array}$ & $\begin{array}{l}3 \cdot 91 \\
(32)\end{array}$ & $\begin{array}{l}2 \cdot 84 \\
(32)\end{array}$ \\
\hline PT & $0 \cdot 80$ & $\begin{array}{l}25 \cdot 31 \\
(57)\end{array}$ & $\begin{array}{l}25 \cdot 45 \\
(52)\end{array}$ & $\begin{array}{l}12 \cdot 34 \\
(57)\end{array}$ & $\begin{array}{l}10 \cdot 68 \\
(57)\end{array}$ & $\begin{array}{l}4 \cdot 11 \\
(57)\end{array}$ & $\begin{array}{l}2 \cdot 97 \\
(57)\end{array}$ \\
\hline RL & 0.89 & $\begin{array}{l}25 \cdot 97 \\
(25)\end{array}$ & $\begin{array}{l}26 \cdot 18 \\
(21)\end{array}$ & $\begin{array}{l}12 \cdot 62 \\
(25)\end{array}$ & $\begin{array}{l}10 \cdot 90 \\
(25)\end{array}$ & $\begin{array}{l}4.05 \\
(25)\end{array}$ & $\begin{array}{l}2 \cdot 93 \\
(25)\end{array}$ \\
\hline $\mathbf{P}$ & $1 \cdot 00$ & $\begin{array}{l}26 \cdot 04 \\
(13)\end{array}$ & $\begin{array}{l}25 \cdot 79 \\
(13)\end{array}$ & $\begin{array}{l}12 \cdot 38 \\
(13)\end{array}$ & $\begin{array}{l}10 \cdot 91 \\
(13)\end{array}$ & $\begin{array}{l}4 \cdot 04 \\
(13)\end{array}$ & $\begin{array}{l}3 \cdot 01 \\
(13)\end{array}$ \\
\hline $\begin{array}{l}r \\
p\end{array}$ & & $\begin{array}{c}0.97 \\
<0.001\end{array}$ & $\begin{array}{l}0.88 \\
0.009\end{array}$ & $\begin{array}{l}0.94 \\
0 \cdot 002\end{array}$ & $\begin{aligned} & 0.95 \\
< & 0.001\end{aligned}$ & $\begin{array}{l}0.93 \\
0.002\end{array}$ & $\begin{array}{l}0.89 \\
0.007\end{array}$ \\
\hline
\end{tabular}

amongst the populations, the fusion $3 / 6$, the interstitial segment and the B-chromosome are not (figs. 1 and 3, table 2), but they clearly follow a geographic pattern. Although non-adaptive arguments, such as historical factors, can be set out to explain the nonrandom distribution of the three ancient polymorphisms (as inferred upon their ubiquity), it can also be used as indirect proof of stabilizing selection acting on them (John, 1981).

Secondly, it was demonstrated that fusion $3 / 6$ produces both intra- and interchromosome effects that lead to a reduction in total recombination (Colombo, 1987; 1988a). Intrachromosome effects consist in suppression of proximal and interstitial chiasmata in the metacentric chromosome, especially in heterozygotes (Colombo, 1987); as stated above, this redistribution is a very important prerequisite for the maintenance of the polymorphism, and was probably achieved through rapid selection against proximal and interstitial chiasmata in the newly arisen metacentric (Hewitt, 1979). The fusion also causes an intrachromosome reduction in total chiasma frequency, which is mainly explained by a lowered number of proximal chiasmata. This effect was attributed to an increase of interference, that would explain both the positive correlation observed between $\mathrm{T}$ and $\mathrm{P}$ mean chiasma frequencies per individual and the negative correlation between I and D (Colombo, unpublished). The results of the interpopulational study developed in this work are consistent with the intrapopulational ones quoted above; mean total and proximal chiasma frequencies per population are negatively correlated with fusion frequency and positively correlated to each other (table 4); likewise, interstitial and distal chiasma frequencies are slightly less affected by fusion frequency but are negatively correlated to each other (table 4, fig. 4).

On the other hand, a highly significant correlation between fusion $3 / 6$ frequency and all mean morphometric measures per population was obtained; and it is further apparent from intrapopulation (between karyomorphys) ANOVA tests that this correlation is due to the fact that fusion carriers (especially fusion homozygotes) are bigger than non-carriers. Hence there seems little doubt that fusion $3 / 6$ (by means of a hypothetical position effect) has a significant effect on exophenotypic characters.

Having in mind both of the effects of fusion $3 / 6$ so far detected (i.e., chiasma and body size effects), some tentative explanations of its nonrandom distribution can be set out:

(1) The geographic distribution of fusion $3 / 6$ resembles the central-marginal pattern of inversion frequencies described in some species of Drosophila (Carson, 1955; Dobzhansky et al., 1963; Brussard, 1984). It is known that ecologically central populations of Drosophila often display a larger extent of inversion polymorphisms than marginal ones. 
This pattern has been attributed by some authors to the fact that marginal populations would need more genotypic variability than central ones in order to face the increased selective pressures that are inherent to peripheral habitats (Carson, 1958; Brussard, 1984).

One of the procedures used in deciding whether a habitat is ecologically central or marginal for a given species is by determining its relative frequency with respect to other species with a similar ecological niche and that would therefore be potential competitors of it. According to this criterion, northern populations of $L$. argentina are visibly more marginal than southern ones, given that in Santa Fe this species shares its habitat with at least three other leptysmine species (namely Leptysmina gracilis, Tucayaca gracilis and Haroldgrantia lignosa, Amedegnato, 1974; Roberts, 1978) that clearly exceed $L$. argentina in density. In "El Palmar" L. argentina is found together with Cylindrotettix obscurus and C. santarosae (also leptysminae), but the density of these species is lower. Finally, southern populations of $L$. argentina are much denser than those of other grasshoppers. Although these qualitative determinations, based upon the relative capture effort necessary to get the sample, are somewhat coarse, they do give some idea of the increased competition that $L$. argentina must undergo in northern populations.

(2) Nonrandom distribution of fusion $3 / 6$ is due to its effect on body size; the biggest individuals would be favoured in southern populations whereas in northern populations the smallest ones would be selected. These differential pressures could be hypothetically attributed to character displacement (Schluter et al., 1985). In southern populations L. argentina is the biggest leptysmine (compared with T. parvula and Stenopola bohlsi). On the contrary, in northern populations $L$. argentina would be displaced in size by $L$. gracilis and the two species of the genus Cylindrotettix, that display approximately the same size as southern $L$. argentina. Fusion $3 / 6$ would be nonadaptive in the north since it produces increased body size, which would enhance competition with other leptysminae.

(3) A third possibility is, of course, that both effects are relevant and that they reinforce one another.

One question that remains to be answered is why selection should "prefer" to act on a chromo- somal polymorphism to achieve an adjustment of chiasma frequency and/or body size, instead of acting on genes that control these characteristics. Genetic studies in plants (Gale and Rees, 1970) and Drosophila (Chinnici, 1971; Kidwell, 1972) demonstrate that recombination is controlled by polygenes that act in an additive way. These polygenes can readily respond to intense directional artificial selection (Shaw, 1972, 1974; Charlesworth and Charlesworth, 1985). However, if selection acts with low coefficients-as is probably the case for chiasma frequency adjustment-the response would be improved if there were a major gene or a chromosomal rearrangement that produced a marked effect on chiasma frequency and/or distribution. Hence, fusion $3 / 6$ polymorphism could confer the necessary plasticity to achieve a rapid response of recombination to the selective pressures. The same reasoning is valid for the exophenotypic effects.

The interstitial segment has no obvious effect on recombination or on body size. John (1981) has stated that some forms of supernumerary heterochromatin polymorphisms may be neutral and consequently transient; however, the vast and nonrandom geographic distribution of $\mathrm{S}_{\mathrm{i}}$ (cf. Results) argues against neutrality for this segment and it is probable in our opinion that some still undetected effect could account for its maintenance.

On the contrary, it looks improbable that $S_{p}$ and the B-chromosome have any positive effect on carriers. Most B-chromosome polymorphisms are thought to be maintained by accumulation mechanisms counterbalanced by negative selection. It is probable therefore that the nonrandom distribution of the B-chromosome of L. argentina reflect a differential tolerance to this element under varied chromosomal, genetical and/or ecological environments. Although it is known that some B-chromosomes can exert chiasma effects that might account for their maintenance in natural populations (Jones and Rees, 1982; Vilardi, 1985; Remis and Vilardi, 1987; Colombo, $1988 \mathrm{~b})$, this seems not to be the case for L. argentina.

The presence of proximal segments of different size in pair 10 suggests that those segments could appear more than once by spontaneous and repeated amplification of heterochromatic sequences contiguous to the centromere (John et al., 1986). The detection of other supernumerary segments in very low frequencies in various populations of $L$. argentina indicates that this mechanism might be common in this species (fig. 1(b)). This fact, along with the marked temporal fluctuation 
of $S_{p}$ (table 2) suggests that this segment could be maintained by mutational input.

L. argentina offers an unusual opportunity to test the effects that very different chromosome polymorphisms exert on meiosis and on exophenotypic traits. This study is necessarily a first approach to this problem, and a much more thorough investigation is required to ascertain the actual causes for the maintenance of chromosomal variability in natural populations in this species.

Acknowledgements The author is grateful to Professor Dr Juan H. Hunziker, Dr Juan C. Vilardi, Lic. Viviana Confalonieri and Lic. Maria 1. Remis for critical reading of the manuscript and helpful discussions. The 13 individuals of $L$. argentina from Pilar (Buenos Aires) were kindly provided by Dr Claudio $J$. Bidau. The taxonomical identification of the leptysmine species mentioned in this paper was made by the distinguished entomologist Dr Ricardo A. Ronderos, to whom the author is especially acknowledged.

Financial support from the Consejo Nacional de Investigaciones Científicas y Técnicas (CONICET) and the Secretaría de Ciencia y Técnica (Argentina) through grants to Drs J. H. Hunziker and C. A. Naranjo is gratefully acknowledged.

\section{REFERENCES}

AMEDEGNATO, C. 1974. Les genres d'acridiens neotropicaux. Leur classification par familles, sous familles et tribus. Acrida, 3, 193-204.

AMOEDO, D. 1979. Estudio citogenético en Leptysma argentina (Orthoptera-Acrididae-Leptysminae). Actas IV Congreso Latinoamericano de Genética (Mendoza, Argentina), 1, 9.

BIDAu, C. J. 1984. Estudios Citogenéticos en Orthoptera de Sudamérica. Ph.D. Thesis, Universidad de Buenos Aires.

BIDAU, C. J. AND HASSON, E. R. 1984. Population cytology of Leptysma argentina Bruner. (Leptysminae: Acrididae). Genetica, 62, 161-175.

BRUSSARD, P. E. 1984. Geographic patterns and environmental gradients: the central marginal model revisited. Ann. Rev. Ecol. Syst., 15, 24-64.

CARSON, H. L. 1955. The genetic characteristics of marginal populations of Drosophila. Cold Spring Harb. Symp. Quant. Biol., 20, 276-287.

CARSON, H. L. 1958. Response to selection under different conditions of recombination in Drosophila. Cold Spring Harb. Symp. Quant. Biol., 23, 291-306.

CHARLESWORTH, B. ANI) CHARLESWORTH, D. 1985. Genetic variation and recombination in Drosophila. II. Genetic analysis of a high recombination stock. Heredity, 54, 85-98.

CHINNIC '1, I. P. 1971. Modification of recombination frequency in Drosophila. II. The polygenic control of crossing over. Genetics, 69, 85-96.

COIOMBO, P. C. 1987. Effects of centric fusions on chiasma frequency and position in Leptysma argentina (Acrididae: Orthoptera). I. Spontaneous and stable polymorphic centric fusions. Genetica, 72, 171-179.
COLOMBO, P. C. 1988a. Polimorfismos cromosónícos en Orthoptera. Actas I Congreso Argentino de Entomología: (in press).

COLOMBO, P. C. 1988 b. Effects of B-chromosomes on recombination in Cylindrotettix obscurus (Leptysminae: Acrididae). Caryologia, (in press).

DOBZHANSKY, TH., HUNTER, A. S., PAVLOVSKY, O., SPASSKY, B. AND WAILACE, B. 1963. Genetics of natural populations XXXI. Genetics of an isolated marginal population of Drosophila pseudoobscura. Genetics, 48, 98-103.

GALE, M. D. AND REES, H. 1970. Genes controlling chiasma frequency in Hordeum. Heredity, 25, 393-410.

HEWITT, G. M. 1979. In John, B. (ed.) Animal Cytogenetics. Vol. 3. Insecta 1. Orthoptera. Gebrueder Borntraeger, BerlinStuttgart.

HEWITT, G. M. AND JOHN, B. 1972. Inter-population sexchromosome polymorphism in the grasshopper Podisma pedestris. II. Population parameters. Chromosoma, 37, 23 42.

HEWI'T, G. M. AND SCHROETER, G. L. 1968. Population cytology of the genus Oedaleonotus. The karyotypic facies of Oedaleonotus enigma Scudder. Chromosoma, 25, 121140.

JOHN, B. 1981. Chromosome change and evolutionary change: a critique. In Atcheley, W. R. and Woodruff, D. S. (eds) Evolution and Speciation, Cambridge University Press, Cambridge, pp. 23-51.

JOHN, B. 1983. The role of chromosome change in the evolution of orthopteroid insects. In Sharma, A. K. and Sharma, A. M. (eds) Chromosomes in the evolution of eukaryotic groups. Vol. 1. C.R.C. Press, Florida, pp. 1 114.

JOHN, B., APPELS, R. AND CONTRERAS, N. 1986. Population cytogenetics of Atractomorpha similis. II. Molecular characterisation of the distal C-polymorphisms. Chromosoma, 94, 45-58.

JOHN, B. AND FREEMAN, M. 1975. Causes and consequences of Robertsonian exchange. Chromosoma, 52, 123-136.

JONES, R. N. AND REES, H. 1982. B-chromosomes. Academic Press: London.

KIDWELL, M. G. 1972. Genetic change of recombination value in Drosophila melanogaster. I. Artificial selection for high and low recombination and some properties of recombination-modifying genes. Genetics, 70, 419-432.

LANDE, F. L. 1979. Effective deme size during long-term evolution estimated from rates of chromosomal rearrangement. Evolution, 33, 234-251.

LUCCHESI, s. 1976. Interchromosomal effects. In Ashburner, M. and Novitski, E. (eds) The Genetics and Biology of Drosophila. Academic Press, London, New York and San Francisco.

RFIMIS, M. I, AND VILARDI, J. C. 1987. Meiotic behaviour and dosage effect of B-chromosomes on recombination in Dichroplus elongatus (Orthoptera: Acrididae). Caryologia, 39, 287-301.

ROBFRTS, M. R. 1978. A revision of the tribe Leptysmini except the genus Cylindrotettix (Orthoptera: Acrididae: Leptysminae). Proc. Nat. Sci. Phil., 129, 33-69.

SCHIUTER, D., PRICE, T. I). AND GRANT, P. R. 1985. Ecological character displacement in Darwin's finches. Science, 227, 1059-1068.

SHAW, D. D. 1972. Genetic and environmental components of chiasma control. II. The response to selection in Schistocerca. Chromosoma, 37, 297-308.

SHAW, D. D. 1974. Genetic and environmental components of chiasma control. III. Genetic analysis of chiasma frequency variation in two selected lines of Schistocerca gregaria Forskål. Chromosoma, 46, 365-374. 
Sybenga, J. 1975. Meiotic Configurations. Monogr. Theor. Appl. Genet. Vol. 1. Berlin-Heidelberg-New York, Springer.

VILARDI, J. C. 1985. Meiotic behaviour in a population of Dichroplus elongatus. (Orthoptera: Acrididae). Caryologia, 38, 147-160.
White, M. J. D. 1973. Animal Cytology and Evolution. 3rd. edn. Cambridge University Press, London.

WHITE, M. J. D. AND MORLEY, F. H. W. 1955. Effects of pericentric rearrangements on recombination in grasshoppers. Genetics, 40, 604-619. 